\title{
The Distributed Profit Based Corporate Taxation, and the Valuation of Cash Holdings
}

\author{
Priit Sander, Allan Teder, Karmen Viikmaa, and Mark Kantšukov
}

\begin{abstract}
The topic of corporate cash holdings has gained a lot of attention in academia recently. The current paper investigates the valuation of cash holdings under distributed profit-based corporate taxation. We show that the cash-to-assets ratio has increased considerably since the introduction of distributed profit-based taxation in Estonia. Almost 1/3 of all the companies in Estonia had cash-to-assets ratios above $50 \%$ in 2011 . We argue that in order to value such cash holdings, a discount at a size of tax burden associated with profit distribution should be used both in case of cash as well as cash equivalents.
\end{abstract}

Index Terms - Cash holdings, company valuation, income taxation.

\section{INTRODUCTION}

Most of the modern corporate finance textbooks focus on the use of DCF based methods (see e.g. [1], [2] etc.). A. Damodaran noted that while relative valuation, i.e. valuation using multiples, is the most widely used valuation method in practice; DCF valuation comes with the best theoretical credentials [3]. There are several papers showing that DCF based valuation is gaining popularity also among practitioners; see e.g. [4], [5].

When applying the DCF based methods, it has been recommended to value non-operating assets separately from the value of operations [6]. These non-operating assets include excess cash holdings, marketable securities, excess real estate, non-consolidated subsidiaries, works of art, etc. One simple alternative to value these assets is to use their current market value, if available.

Over the past decades, US corporations have increased the fraction of their assets held as cash [7]. According to Gao, Harford, and Li (2013) public firms in the US held, on average, $20.45 \%$ of their assets in cash or near-cash instruments as of end of 2011 [8]. Similar tendencies have been witnessed in Europe too (see e.g. [9]).

The aim of the article is to discuss some methodological problems arising in valuation of excess cash holdings under distributed profit taxation system. The number of papers investigating the economic consequences of distributed profit based tax system is still rather limited, but slowly growing. Hazak (2008) investigated the impact of distributed profit taxation system on dividend and capital structure decisions of companies [10]. Sander and Kantšukov (2009) investigated the effect of corporate taxation system on profitability and

Manuscript received December 9, 2013; revised March 31, 2014

The authors are with the University of Tartu, Estonia (e-mail priit.sander@ut.ee). market ratios [11]. Masso, Meriküll, and Vahter (2011) studied the effect of the corporate tax reform in Estonia on various aspects of corporate behavior (financing, profit distribution, investment) [12]. The macroeconomic influence of distributed profit taxation system has been researched in several papers, most recently by Masso and Meriküll (2011) [13]. However, to the authors' best knowledge there are no previous papers dealing with the valuation of cash holdings under distributed profit taxation.

The paper is structured as follows. The first section provides the rationale of holding excess cash and discusses main factors that affect the market value of cash based on previous literature. The next section explains the main differences between classical gross profit corporate taxation and distributed profit corporate taxation regimes and analyzes the impact of distributed profit taxation on the motivation of piling up excess cash as well as how this cash should be valued. The last section provides some empirical evidence about cash holdings of Estonian companies. Our study employs both aggregate data for the corporate sector as a whole as well as firm level data to describe the trends and regularities in cash holdings of Estonian companies.

\section{CORPORATE CASH HOLdING AND THE VAlue OF CASH: A LITERATURE OVERVIEW}

Previously various motives for firms' cash holdings have been identified in finance literature. Already Keynes (1936) indicated that firms follow the transaction and precautionary motives when choosing the amount of cash on their balance sheets [14].

According to the transaction motive, firms hold cash for daily transactions and by doing that they can lower transaction costs from not having to liquidate assets when facing a payment. In this case there is much evidence supporting the existence of the economies of scale, i.e. cash-to-assets ratio of large companies is usually lower (see e.g. [15]). Opler, Pinkowitz, Stultz, and Williamson (1999) summarized main implications of transaction cost-based model. The higher the volatility of cash flows and the longer the cash conversion cycle the more liquid assets companies hold. The model also implies that liquid asset holdings decrease with interest rates and the slope of the term structure, with the cost of raising debt, with the ease of selling assets, with the cost of hedging risk, and with the size of a firm's dividend [16].

According to precautionary motive firms hold cash in order to be able to launch projects with positive NPV even in times when external finance (both debt and equity) is costly. This motive is particularly important to firms that have good 
investment opportunities but are unable to generate enough internal cash to take advantage of them. Han and Qiu (2007) provide evidence that financially constrained firm increases its cash holdings in response to an increase in cash flow volatility. In contrast, no systematic relationship between cash holding and cash flow volatility for unconstrained firms was found [17]. According to Myers and Majluf (1984), the precautionary motive for holding cash should be more relevant if asymmetric information between investors and management makes external financing costly. According to the pecking order theory, firms prefer internal equity to finance their activities and thus pile up cash and do not use fully their borrowing capacity as without such financial slack, firms may pass up positive NPV projects, leading to underinvestment [18].

Another stream of literature investigates the impact of conflict of interest on corporate cash holdings. Jensen (1986) argued that entrenched managers would rather retain cash than make payouts to shareholders when the firm has poor investment opportunities [19]. In Dittmar, Mahrt-Smith, and Servaes (2003), cross-country evidence indicated that firms hold more cash in countries with greater agency problems [20]. A study by Bertrand and Mullainathan (2003) suggests that desire of a chief executive officer for a quiet life, would lead to a higher-than-optimal buffer of cash holdings [21].

In some countries (e.g. United States) tax motives play important role for piling up the cash. US multinational firms hold cash in their foreign subsidiaries because of the tax costs associated with repatriating foreign income. This does not necessarily mean that cash is physically abroad; many large companies keep their money in the US banks or in US government and corporate securities [22]. Due to the absence of parent-subsidiary regime multinationals have to pay hefty taxes when repatriating their foreign earnings. Foley, Hartzell, Titman, and Twite (2006) provide empirical evidence that US corporations that would incur tax consequences associated with repatriating foreign earnings hold indeed higher levels of cash [23]. Also one can notice that corporation employing pretty sophisticated tax avoidance schemes, such as Double Irish and Dutch Sandwich, usually have higher amounts of cash piled up on their balance sheets [24], [25].

However, taxes can also reduce the propensity to hold cash. Under the classical corporate income taxation, taxes increase the cost of holding liquid assets. Since the interest income from liquid assets is taxed twice, first at the corporate level, and then taxed again at the individual level as it generates taxable income for the shareholders. This may lead shareholders to prefer that excess cash would be returned to shareholders and not invested into liquid assets [16].

Recent studies have found that size of cash holdings depends on stock liquidity [26]; that cash holdings have been used to discourage market competitors [27], and that cash plays a great strategic role in company's future product market performance [28].

While there is ample research about the motives for holding cash, the question remains - what is the value of one dollar held in cash by the firm? In a perfect capital market such cash would be valued dollar for dollar by shareholders. In such environment it is irrelevant whether the firm pays out cash or holds on to. A firm can always finance positive NPV project by raising debt or outside equity. However, if capital markets are imperfect then a dollar held by the firm may not be valued at a face value by investors.

In fact, one dollar of a company's cash is only worth one dollar if the company is able to invest it at its cost of capital, or failing that, to return it to its providers of funds through share buybacks or dividends or the advance repayment of debt. An exception can be made for reasonable amounts of cash or cash waiting to be reinvested in the business.

Different studies have found great variation in value investors put on a dollar held as cash. Pinkowitz and Williamson (2004) found that on average, shareholders value a marginal dollar of cash at face value but the cross-sectional variation was quite wide - the marginal value of cash ranged from $\$ 0.27$ to $\$ 1.76$. Firms with poor growth options, those with more predictable investment opportunities, and those nearer to financial distress had their cash valued at a significant discount to book value [29]. Several studies have emphasized the role of corporate governance in valuation of cash [9], [30], [31]. Firms with poor governance dissipate cash quickly. In such companies cash is valued considerably lower than its book value, but good corporate governance approximately doubles the value of cash. The market value of cash is higher in countries with good minority investor protection.

Also, taxes affect the valuation of cash. Dhaliwal, Huang, Moser, and Pereira (2011) argued that investor valuation of firm cash holdings is lower for firms with higher levels of tax avoidance [32]. Bryant-Kutcher, Eiler, and Guenther (2008) concluded that financial assets held by US multinationals abroad are valued less that operating assets due to the taxes associated with repatriation of foreign earnings [33].

Next, we characterize so-called distributed profit corporate taxation system and discuss the main implications of such system on the size and value of cash holdings.

\section{Distributed PROFIT CORPORATE TAXATION}

The distributed profit based corporate taxation was experimentally introduced by Estonian government in 2000 . In 2008, a rather similar tax system was adopted by Republic of Macedonia. To date only these two countries operate under distributed profit taxation (DPT) system.

The main difference between classical (or - traditional) profit based corporate taxation, which is used in most countries, and distributed profit based corporate taxation is that under latter system the moment of corporate taxation has been shifted from the period of earning the profit to the period of distributing it. According to the Estonian tax system, both explicit (dividends, share repurchases, etc) and implicit (fringe benefits, expenses unrelated to business, etc.) distributions of profits are taxed at the same rate. Retained profits, on the other hand, are not taxed. Such system clearly simplified tax accounting for companies (i.e. there is no need for rules concerning tax depreciation, loss carry-forwards or carry-backs, thin capitalization etc), but also created some confusion among practitioners regarding application of financial models and theoretical recommendations found in corporate finance textbooks. 
One of the goals of distributed profit taxation system introduction in Estonia was to encourage investment activity. Empirical investigation by Hazak (2008) confirmed that DPT system had led companies to pay lower dividends and retain more profits. However, undistributed profits appear to be partially retained as surplus cash, instead of being reinvested into long-term assets into companies' core businesses [10].

Under distributed profit taxation system, firms can freely (i.e. without imposing any tax burden) sell their assets as long as receipts are kept inside the company. However, any distribution of profit will result in tax liability. Therefore, while company's funds are not tied up to some specific investment, they are still partially locked inside the company.

Let's suppose a company has some amount of profit which can be either distributed to the owners or reinvested into the company with expected rate of return $r_{1}$. If the firm chooses to distribute the profit, it has to pay the corporate income tax at the rate of $t_{1}$. However, if it chooses to reinvest, it has to pay taxes at the rate of $t_{2}$ at the end of investment period with the length of $n$ years. The same proportional tax rates also apply at personal level and there is no double taxation, i.e. no income taxes on dividend income. We could ask what expected rate of return $\left(r_{2}\right)$ the owners should earn on their personal investment for preferring payout to reinvestment made by the company. Hereby we assume that investment made by the owner is not available for the company. Also it is assumed that received dividends are reinvested by the owners.

If the company decides to reinvest and distribute the profit only at the end of the investment horizon, the after tax wealth $\left(W_{1}\right)$ of it owners can be calculated as follows:

$$
W_{1}=P \cdot\left(1+r_{1}\right)^{n}-t_{2} \cdot P \cdot\left(1+r_{1}\right)^{n}
$$

where $P$ denotes the existing profit (retained earnings) at the current moment.

If the company chooses the payout and the owners reinvest net dividend on their own at expected rate of return $r_{2}$, the after-tax wealth of the owners $\left(W_{2}\right)$ after $n$ years can be calculated as follows:

$$
\begin{aligned}
& W_{2}=P \cdot\left(1-t_{1}\right) \cdot\left(1+r_{2}\right)^{n}- \\
& -t_{2} \cdot\left[P \cdot\left(1-t_{1}\right) \cdot\left(1+r_{2}\right)^{n}-P \cdot\left(1-t_{1}\right)\right]
\end{aligned}
$$

The company should favor the distribution of profit if the $W_{2}>W_{1}$. By rearranging we get that the condition for the firm to prefer distribution over reinvestment is as follows:

$$
r_{2}>\sqrt[n]{\frac{\left(1+r_{1}\right)^{n}}{1-t_{1}}-\frac{t_{2}}{1-t_{2}}}-1
$$

Under the constant or declining tax rates shareholders prefer distribution only when $r_{2}>r_{1}$, i.e. only if the owners of the company have more profitable investment available than the company itself.

The following numerical example will help to illustrate the issue. Let's suppose that the tax rate is $21 \%$ (income tax rate in Estonia currently) and the firm can reinvest retained earnings for one year with expected rate of return of $10 \%$. If the tax rate is constant over time, the owners have to earn more than $12.66 \%$ on their personal investments in order profit distribution to be reasonable. However, if the tax rate is going to decline to $20 \%$ after a year, it would be reasonable to distribute profits in the current year only if the owners can achieve the return of $14.24 \%$ on their personal investments.

The longer the investment horizon, the smaller the difference between rates of returns inside and outside the company has to be for shareholders to be indifferent between retaining and distributing the profit (see Fig. 1). Also, the impact of declining tax rates diminishes quickly when the investment horizon lengthens.

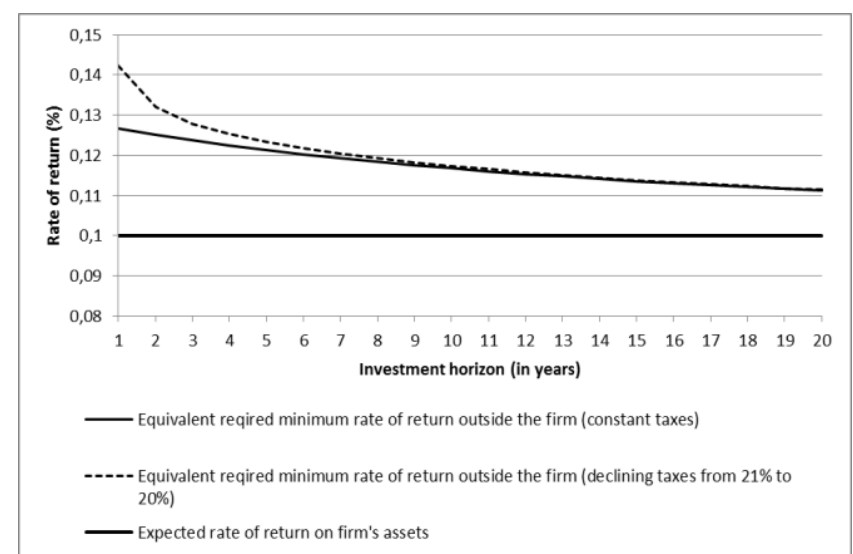

Fig. 1. The relationship between investment horizon and relative strength of lock-in effect under the distributed profit taxation system.

Relatively low propensity of Estonian companies to pay out dividends (see e.g. [34]) can thus be justified by the specific features of Estonian corporation taxation rules. But how should cash instruments be valued under such taxation rules?

As the previous literature overview demonstrated, there are many aspects that affect the value of cash holdings future investment opportunities, financing constraints, investor protection, level of corporate governance, etc. We will detach from those aspects for a moment and look things solely from the taxation point of view.

A large part of cash holdings appears in the form of bank deposits. In Estonia, interests paid by banks to private persons are tax exempt. This does not apply to firms, i.e. interest income is a component of the company's net profit, and it is taxed similarly to income from any other source, when company decides to distribute the profits. As long as the pre-tax interest rate paid to the private persons is equal or exceeds the interest rate paid to firms, there are actually no tax-based reasons to value such excess cash higher than book value minus taxes the company has to pay when distributing the cash to shareholders. The same applies to the pure cash.

The excess cash by definition may also include short-term marketable securities. In Estonia the general rule is that interest payments are taxed at individual level as ordinary income (the only exception is interest received from deposits with a credit institution which is a resident of a Contracting State of the European Economic Area agreement or through or on account of a permanent establishment of a credit institution located in a Contracting State [35]). In case the firm has invested its cash into such securities (and assuming that interest rate on these securities on after-tax level is at least as high as pre-tax interest rates on bank deposits), there 
is a tax advantage of using the firm as a piggy bank. But while that tax advantage exists, it does not cover the full tax burden associated with taxation of cash distribution on corporate level. The discount $(d)$, under the assumption of constant tax rate, can be calculated as follows:

$$
d=\frac{t \cdot V_{s}}{(1+r)^{n}},
$$

where $r$ denotes the rate of return, $t$ is corporate tax rate, $V_{s}$ in the value of marketable securities, and $n$ is the length of investment horizon. In case of a very long investment horizon and high rate of return, the discount approaches zero but as short-term financial instruments usually offer relatively low return, the discount can be also quite near to the tax burden associated with the distribution of earnings.

The distribution of cash can be done either in the form of dividends, share repurchases or payments associated with share capital reduction. In case of share repurchases and capital reduction, the company has to pay taxes only on amount by which payments to shareholders exceed paid-in capital. In case of dividends, the total payment will be taxed, with some minor exemptions. Obviously some cash is needed for daily operations, can be used for repayment of debt or is held for the future investments into operating assets, but the rest will demand a discount in valuation process.

\section{CASH HOLDINGS IN ESTONIAN COMPANIES: EMPIRICAL EVIDENCE}

We begin with the overview based on aggregate corporate sector data, collected by Statistics Estonia. This database includes all firms with 20 or more employees and random sample of smaller privately held firms. Firms from financial sector, farmsteads and public sector organizations are excluded. The data show, that similarly to other European countries and United States, the cash holdings have increased considerably during the last 15 years (see Fig. 2).

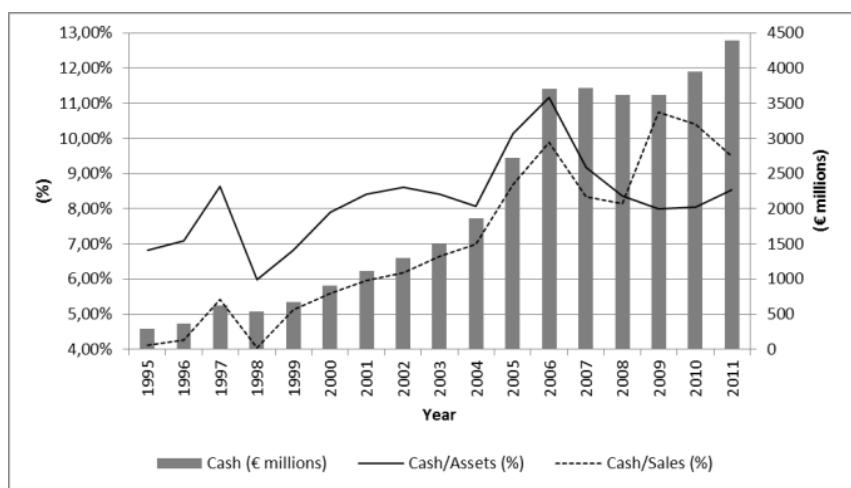

Fig. 2. Aggregate cash holdings, cash-to-assets and cash-to-sales ratio of Estonian firms 1995-2011 (Source: Statistics Estonia Database, authors' calculations).

We can also see that during the economic downturns (1998-1999, and 2009-2010), the level of cash as well as cash-to-assets ratio have decreased. This can be explained by two different aspects. Some firms that experienced economic difficulties used their cash reserves to survive; other firms paid out large dividends despite dropping revenues and profits (e.g. according to Sander, Kariler, and Viikmaa (2013) the aggregate corporate profits decreased 3 times, while aggregate dividends decreased only $10 \%$ in 2009 and total dividends exceeded net income by $20 \%$ in that year) [34].

While cash-to-assets ratio is higher today than it was before the income tax reform in 2000, the Estonian Statistical Office data underestimates remarkably actual average cash-to-assets ratio due to the fact that only a fraction of small companies are included into the sample.

Therefore we analyzed firm level data obtained from the Estonia Commercial Register. The data indicated that the average cash-to-assets ratios were approximately three times higher if all companies we taken into consideration (see Fig. 3). Also, the impact of financial crises has been reflected clearly in the size of average cash holdings.

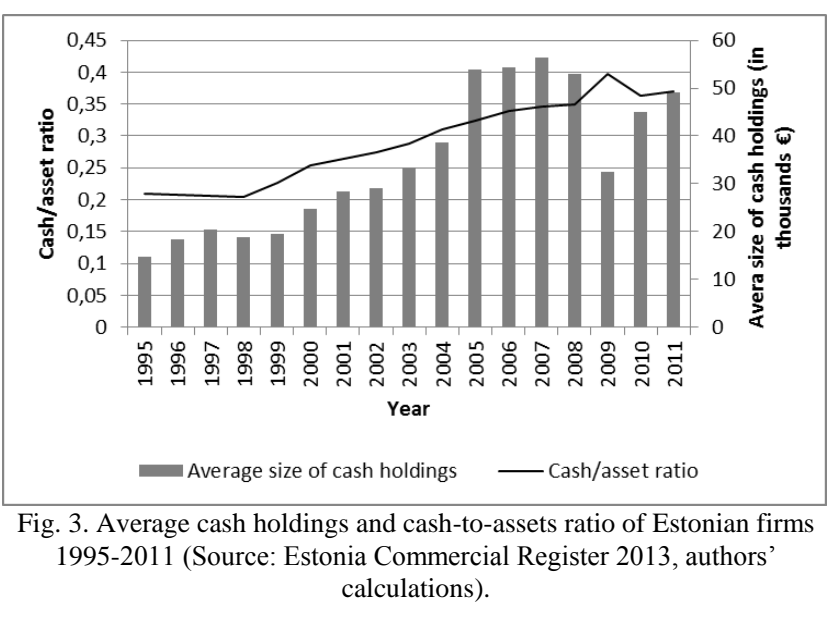

Next we analyze more thoroughly the distribution of firms based on values of cash-to-assets ratio. There were in total 89500 firms registered as of end of 2011. After excluding observations with missing or illogical values (e.g. companies with negative value of assets etc.) our sample still contained more than 82000 Estonian firms. The distribution of firms based on values of cash-to-assets ratio (see Fig. 4) showed an interesting picture. While there are many companies without any considerable excess cash (almost $30 \%$ of companies had cash-to-assets ratio less than $10 \%$ ), the number of companies with cash holdings more than $50 \%$ of balance sheet amount is astonishing. In one third of Estonian companies cash-to-assets ratio is over $50 \%$, and there are approximately 12000 firms in which cash constitute more than $95 \%$ of balance sheet.

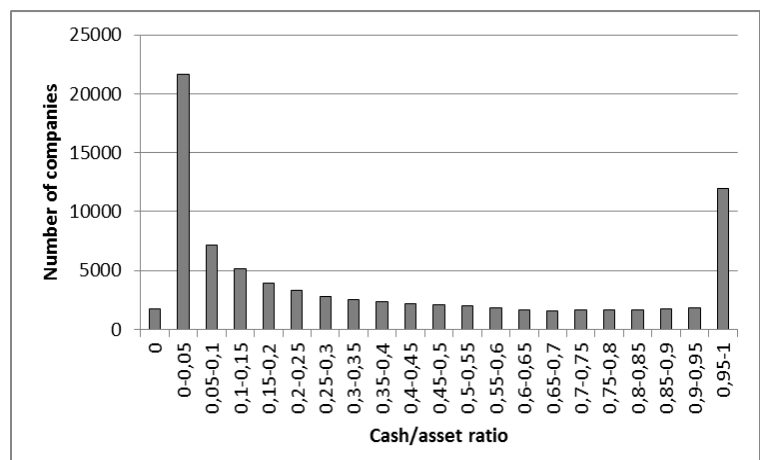

Fig. 4. Distribution of Estonian companies based on the cash-to-assets ratio in 2011 (Source: Estonia Commercial Register 2013, authors' calculations.) 
Most of these extremely cash-abundant companies are considerably smaller than the average Estonian firm, less active (i.e. firms with smaller sales revenue), less profitable and younger (see Table I below). We hypothesize that many of them were created for reasons of tax avoidance, for just one or a few transactions, or for investment purposes. Cash-to-assets ratio was especially high in firms which business is based on human capital, i.e. firms operating in the fields like scientific research and development, healthcare activities (dentists, local general practitioners), computer programming, consultancy and related activities, etc.

TABLE I: CHARACTERISTICS OF AVERAGE VERSUS CASH-ABUNDANT FIRMS IN ESTONIA IN 2011 (SOURCE: ESTONIA COMMERCIAL REGISTER 2013, AUTHORS' CALCULATIONS)

\begin{tabular}{lll}
\hline \hline & $\begin{array}{l}\text { Average } \\
\text { (median) } \\
\text { company }\end{array}$ & $\begin{array}{l}\text { Average (median) company } \\
\text { with cash-to-assets ratio } \\
>95 \%\end{array}$ \\
\hline Age (years) & $7.1(6)$ & $5.4(4)$ \\
Assets (mio EUR) & $0.62(0.025)$ & $0.015(0.003)$ \\
Sales revenue (mio & $0.53(0.024)$ & $0.017(0.0002)$ \\
EUR) & $0.037(0.005)$ & $0.001(0)$ \\
Net profit (mio EUR) & & \\
\hline \hline
\end{tabular}

Similarly to previous studies (e.g. Mulligan 1997) we found that cash-to-assets ratio depends heavily on the size of the company expressed in books value of assets (see Fig. 5). Firms with book assets over one million Euros have cash-to-assets ratio less than $10 \%$ on average. In smaller companies (with assets less than 10 thousand euros) this figure exceeds $50 \%$.

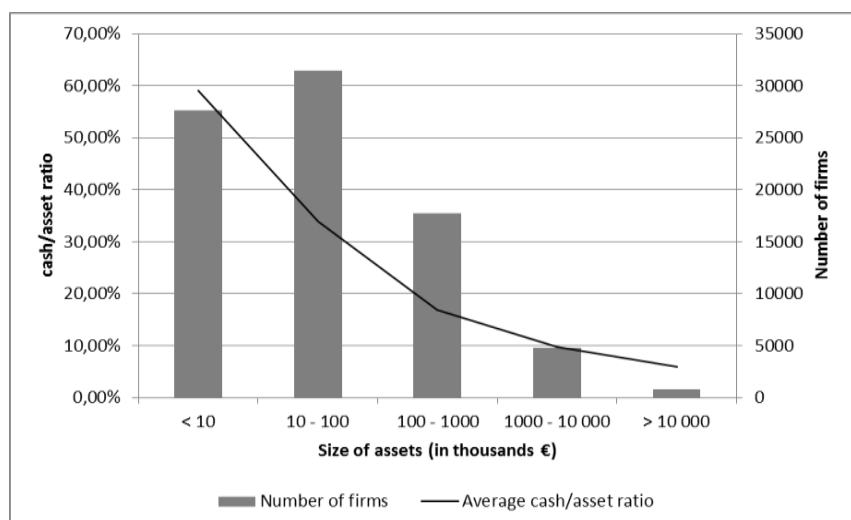

Fig. 5. The relationship between cash-to-assets ratio and the size of assets in Estonian firms in 2011 .

The empirical evidence confirm that cash holdings play important role in Estonian companies - the average cash-to-assets ratio is high and has been increase a lot since the income tax reform in 2000. While very high cash-to-assets ratios are mainly characteristic to small companies, there were around 30 firms with more than 10 million euros as cash in their balance sheets in 2011.

\section{CONCLUSIONS}

The propensity to hold cash depends on several different factors. In the current paper we investigated corporate cash holdings under the distributed corporate profit taxation regime. While the taxes are just one variable affecting the decisions about retaining or distributing cash, they are important both for the amount as well as the value of cash holdings. In Estonia, the moment of corporate taxation has been shifted from the period of earning the profit to the period of distributing it. Such a system creates strong motive for retaining earnings. Empirical data have confirmed that cash-to-assets ratio has increased considerably since the tax reform in 2000. Cash-to-assets ratio is dependent on the firm size as well as industry. In micro companies cash constitutes more than a half of their balance sheet. In valuing such cash, one should take into account the specific features of the tax system. In Estonia, a discount to cash as well as cash equivalents (bank deposits first of all) should be applied in the valuation process, which in the most cases should equal the tax burden associated with the distribution of profits.

\section{ACKNOWLEDGMENT}

The study has been prepared with financial support received from Estonian Ministry of Education and Research funding SF0180037s08. The authors are thankful to Jaan Masso for providing the detailed financial data from Estonia Commercial Register database.

\section{REFERENCES}

[1] P. Vernimmen, P. Quiry, M. Dallocchio, Y. L. Fur, and A. Salvi, Corporate Finance. Theory and Practice, $3^{\text {rd }}$ edition, John Wiley \& Sons, 2011.

[2] T. E. Copeland, J. F. Weston, and K. Shastri, Financial Theory and Corporate Policy, $4^{\text {th }}$ edition, Pearson Addison-Weasly, 2005.

[3] A. Damodaran. (June 14, 2010). Valuation approaches and metrics: A survey of the theory and evidence. Foundations and Trends in Finance. [Online]. p. 92. Available: http://ssrn.com/abstract $=1625010$

[4] S. Imam, R. Barker, and C. Clubb, "The use of valuation models by UK investment analysts," European Accounting Review, vol. 17, issue 3, pp. $503-535,2008$

[5] T. K. Mukherjee, H. Kiymaz, and H. K. Baker, "Merger motives and target valuation: A survey of evidence from CFOs," Journal of Applied Finance, vol. 14, pp. 7-24, Fall/Winter 2004.

[6] T. Koller, M. Goedhart, and D. Wessels, Valuation: Measuring and Managing the Value of Companies, $4^{\text {th }}$ ed. Hoboken, New Jersey: Wiley \& Sons, 2005.

[7] T. W. Bates, K. M. Kahle, and R. M. Stulz, "Why do U.S. firms hold so much more cash than they used to?" Journal of Finance, vol. 64, pp. 1985-2022, October 2009.

[8] H. Gao, J. Harford, and K. Li, "Determinants of corporate cash policy: Insights from private firms," Journal of Financial Economics, vol. 109 pp. 623-639, September 2013.

[9] M. B. J. Schauten, D. van Djik, and J.-P. van der Waal, "Corporate governance and the value of excess cash holdings of large European firms," European Financial Management, vol. 19, pp. 991-1016, November 2013.

[10] A. Hazak, "Capital structure and dividend decisions under distributed profit taxation,” Ph.D. dissertation, Dept. Econ., Tallinn University of Technology, 2008.

[11] P. Sander and M. Kantšukov, "Effect of corporate taxation system on profitability and market ratios: the case of ROE and P/B ratios," Research in Economics and Business: Central and Eastern Europe, vol. 1, pp. 27-40, Feb. 2009.

[12] J. Masso, J. Meriküll, and P. Vahter, "Gross profit taxation versus distributed profit taxation and firm performance: effects of Estonia's corporate income tax reform," The University of Tartu Faculty of Economics and Business Administration, Working Paper No. 81-2011, p. 33, March 2011.

[13] J. Masso and J. Meriküll "Macroeconomic effects of zero corporate income tax on retained earnings" Baltic Journal of Economics, vol. 11, pp. 81-99, 2011.

[14] J. M. Keynes, The General Theory of Employment, Interest and Money, McMillan, London, 1936.

[15] C. B. Mulligan, "Scale economies, the value of time, and the demand for money: longitudinal evidence from firms," Journal of Political Economy, vol. 105, pp. 1061-1079, October 1997 
[16] T. Opler, L. Pinkowitz, R. Stultz, and R. Williamson, "The determinants and implications of corporate cash holdings," Journal of Financial Economics, vol. 52, pp. 3-46, April 1999.

[17] S. Han and J. Qiu, "Corporate precautionary cash holdings," Journal of Corporate Finance, vol. 13, pp. 43-57, March 2007.

[18] S. C. Myers and N. S. Majluf, "Corporate financing and investment decisions when firms have information that investors do not have," Journal of Financial Economics, vol. 13, pp. 187-221, June 1984.

[19] M. C. Jensen, "Agency cost of free cash flow, corporate finance, and takeovers," American Economic Review, vol. 76, pp. 323-329, May 1986.

[20] A. Dittmar, J. Mahrt-Smith, and H. Servaes, "International corporate governance and corporate cash holdings," Journal of Financial and Quantitative Analysis, vol. 38, pp. 111-133, March 2003.

[21] M. Bertrand and S. Mullainathan, "Enjoying the quiet life? Corporate governance and managerial preferences," Journal of Political Economy, vol. 111, pp. 1043-1075, October 2003.

[22] K. Linebaugh, "Firms Keep Stockpiles of 'Foreign' Cash in U.S.," Wall Street Journal Online, January 22, 2013

[23] C. F. Foley, J. C. Hartzell, S. Titman, and G. Twite, "Why do firms hold so much cash? A Tax-based explanation," NBER Working Paper Series, no. 12649, October 2006.

[24] C. Duhigg and D. Kociniewski, "How Apple Sidesteps Billions in Taxes," New York Times, April 28, 2012.

[25] J. Drucker, "Google 2.4\% Rate Shows How \$60 Billion Lost to Tax Loopholes," Bloomberg, October 1, 2010.

[26] K. G. Nyborg and Z. Wang, "Stock liquidity and corporate cash holdings" Swiss Finance Institute, Research Paper Series, no. 13-36, p. 51, June 2013.

[27] J-P. Benoit, "Financially constrained entry in a game with incomplete information," Rand Journal of Economics, vol. 15, pp. 490-499, Winter 1984

[28] L. Fresard, "Financial strength and product market behavior: the real effects of corporate cash holdings," Journal of Finance, vol. 65, pp 1097-1122, June 2010.

[29] L. Pinkowitz and R. Williamson, "What is a dollar worth? The market value of cash holdings," Georgetown University, p. 39, 2004.

[30] A. Dittmar and J. Mahrt-Smith, "Corporate governance and the value of cash holdings," Journal of Financial Economics, vol. 83, pp. 599-634, March 2007.

[31] L. Pinkowitz, R. M. Stulz, and R. Williamson, "Do firms in countries with poor protection of investor rights hold more cash?" Journal of Finance, vol. 61, pp. 2725-2751, December 2006.

[32] D. S. Dhaliwal, S. X. Huang, W. Moser, and R. Pereira. (March 2011). Corporate tax avoidance and the level and valuation of firm cash holdings. [Online]. p. 41, Available: http://ssrn.com/abstract=1800140

[33] L. Bryant-Kutcher, L. Eiler, and D. A. Guenther, "Taxes and financial assets: Valuing permanently reinvested foreign earnings," National Tax Journal, vol. 61, pp. 699-720, December 2008.
[34] P. Sander, J. Kariler, and K. Viikmaa, "Recent trends in dividend policy of Estonian companies," Journal of International Scientific Publications: Economy \& Business, vol. 7, pp. 4-14, 2013.

[35] Income Tax Act of Estonia. [Online]. Available: http://www.legaltext.ee/text/en/X40007K18.htm

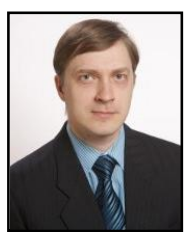

P. Sander holds PhD in economics and is employed as an associated professor in finance at the University of Tartu.

His current research focuses on company valuation in emerging markets, dividend and financing policy, tax-based trading strategies and other financial topics. He has also consulted firms in business valuation cases.

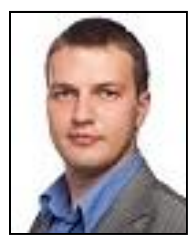

A. Teder is currently a $\mathrm{PhD}$ student in the University of Tartu and is researching financial markets from the perspective of participants. He is employed by a start-up firm AT Systems OÜ which develops and applies trading algorithms.

His current research focuses on testing various events that influence the price dynamics of a certain financial asset and perform relevant tests. Other areas of interest include pattern recognition and fundamental analysis of economic data.

K. Viikmaa is currently a PhD student in the University of Tartu and is researching financial contagion with special emphasis on banking crises.

His current research focuses on systemic risk which evolved from the current financial crisis in banking sector and ways these risks can be ameliorated. Additional focus strives to explore the ideas of ways to ameliorate outcomes of the global crisis and mitigate common risks with reference to the flawed regulations.

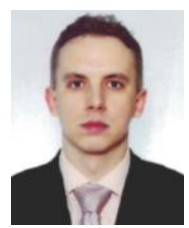

Mark Kantšukov received his MA degree from the University of Tartu and is currently working as a lecturer in finance at the University of Tartu, Faculty of Economics and Business Administration (Estonia). His research interests lay in the field of corporate finance and investments, especially in corporate and asset valuation. $\mathrm{He}$ is also interested in financial modeling, behavioral finance, and financial fraud. He has published several research papers on aforementioned topics. 